\title{
Paikallissijaisten saneiden funktiot ruotsinkielisten alkeistason suomenoppijoiden teksteissä
}

\author{
TUIJA M Ä̈̈TTÄ \\ Uumajan yliopisto
}

Tiivistelmä. Artikkeli käsittelee ruotsinkielisten suomenoppijoiden paikallissijojen esiintymistä ja käyttöä eri funktioissa. Tutkimus on korpuspohjainen. Aineistosta erottuu neljä funktioryhmää: paikka, aika, rektioverbit ja muut. Ryhmään muut on sijoitettu toisistaan hyvin poikkeavia funktioryhmiä, joihin kuuluu vain muutamia tapauksia. Artikkelissa tarkastellaan lisäksi, miten norminmukaisia ja norminvastaisia paikallissijaisia saneita esiintyy eri funktioissa ja pohditaan syitä norminvastaisten paikallissijojen käyttöihin. Tulokset osoittavat, että oppijat kykenevät hyvin valitsemaan eri funktioihin sopivan paikallissijan. Norminvastaisissa tapauksissa on useimmiten kyse väärän paikallissijan valinnasta. Oppijat hahmottavat tekemisen suunnan mutta tilan ulkoisuus tai sisäisyys ei ole kaikissa konteksteissa selvä. Suurin osa paikallissijaisista saneista on konkreettisen paikan funktiossa, ja tavallisimmat sijat ovat inessiivi ja illatiivi. Myös adessiiviset ajanilmaukset, allatiivisen ja elatiivisen täydennyksen vaativat rektioverbit ja omistuslauseet ovat taajaan esiintyviä.

Avainsanat: oppijansuomi; ruotsinkielinen oppija; alkeistaso; paikallissijat; paikallissijaisten saneiden funktiot; korpuspohjainen tutkimus 


\section{Johdanto}

Suomen kielessä paikallissijoilla on keskeinen asema, ja niillä on useita funktioita. Eri paikallissijoja voidaan käyttää yhdessä tietyssä funktiossa ja yhtä paikallissijaa puolestaan monissa funktioissa. (Grönholm 2009: 197.) Myös suomi toisena tai vieraana kielenä -opetukseen (S2) suunnatuissa oppikirjoissa paikallissijat esitellään aikaisin. Ensimmäisenä sijoja opetellaan käyttämään paikan funktiossa, ja sitten oppijat tutustutetaan myös paikallissijaisiin ajanilmauksiin ja omistuslauseeseen. (Koskela \& Suni 2000: 142-143.)

Suomen kieli on morfologisesti rikas kieli, ja S2-opetuksessakin on pitkään painotettu muoto-opin tärkeyttä. Pelkkä sanan muodon oppiminen ei kuitenkaan riitä vaan on otettava huomioon myös sanan merkitys. Uuden kielen oppijalla sanojen muodot ja merkitysten ilmaisimet, kuten sijapäätteet, saattavat sekoittua, mikä on luonnollista oppijankielessä. Ajan myötä muoto ja merkitys alkavat kuitenkin vastata toisiaan automaattisesti. (Lauranto 1997: 68-69.)

Ruotsinkielisten suomenoppijoiden kirjallisissa tuotoksissa on paljon paikallissijaisia saneita. Tässä artikkelissa analysoin, millaisissa funktioissa saneet esiintyvät. Funktiolla tarkoitan sitä, missä tehtävässä, esimerkiksi paikan ja ajan ilmaisijana, paikallissijainen sane toimii lauseessa. Lisäksi käsittelen erikseen norminmukaisia ja norminvastaisia paikallissijaisten saneiden esiintymiä funktioissa ja pohdin syitä, jotka mahdollisesti ovat vaikuttaneet väärään sijanvalintaan. Tutkimuksen tavoitteena on saada tietoa funktioiden yleisyydestä ja siitä, mitä paikallissijoja oppijat käyttävät eri funktioissa. Tavoitteena on myös saada kuva siitä, mitä funktioita ja niissä esiintyviä paikallissijoja oppijat hallitsevat, ja myös löytää mahdolliset ongelmakohdat, joita oppijoilla ehkä on. Tulokset palvelevat käytännön tarpeita, koska ne ovat suoraan sovellettavissa oppijoiden eduksi. Niin positiivisia kuin negatiivisiakin tuloksia voi hyödyntää esimerkiksi oppitunneilla ja oppimateriaalien laadinnassa.

Artikkelini koostuu kolmesta osiosta. Ensimmäisessä osiossa esittelen kaikkien aineistossa olevien paikallissijaisten saneiden funktiot ja 
analysoin ne funktioittain. Tässä vaiheessa ovat mukana sekä norminmukaiset että norminvastaiset esiintymät. Toisessa osiossa käsittelen norminmukaisten paikallissijaisten saneiden funktioita ja kolmannessa osiossa norminvastaisten paikallissijaisten saneiden funktioita.

Oppijansuomen paikallissijoista on jo monenlaisia tutkimuksia eri näkökulmista. Muun muassa espanjankielisten oppijoiden paikallissijojen käyttöä on tarkasteltu konseptuaalisen semantiikan näkökulmasta (Lauranto 1997), ja islanninkielisten oppijoiden kirjoitelmista on tutkittu paikallissijoissa esiintyviä virheitä ja paikallissijojen merkityksiä (Ampula 2002). Aikuisten ja koululaisten paikallissijojen konkreettista ja abstraktista käyttöä on tarkasteltu myös taitotasojen näkökulmasta (Martin ym. 2010). Tutkimuksessa selvitetään myös staattisen ja dynaamisen käytön eroavaisuuksia. Myös ruotsinkielisten oppijoiden paikallissijojen käyttöä on kartoitettu, ja tutkimuksessa analysoidaan lisäksi, millaisia norminvastaisuuksia tuotoksissa esiintyy (Määttä 2011). Siivelt (2012) on tutkinut vironkielisten suomenoppijoiden sisäpaikallissijojen käyttöä, etenkin lähdekielen vaikutuksen ilmenemistä eri kielitaitotasoilla.

Tutkimuksessani käytän virheanalyysiä ja kontrastiivista metodia. Virheanalyysin avulla saadaan esiin funktioissa käytettyjen paikallissijojen norminmukaisuus tai norminvastaisuus, ja kontrastiivinen näkökulma tulee esiin esimerkkien analysoinneissani.

Uuden kielen oppiminen on aikaa vievä prosessi. Oppijan kieli kehittyy vaiheittain, ja eri vaiheissa oppijalla esiintyy kohdekielestä poikkeavia muotoja. Tärkeä kysymys on, kuinka paljon oppijan tekemiin poikkeamiin tulisi kiinnittää huomiota ja millä tavalla niitä tulisi korjata ja selittää oppijalle. (Sajavaara 1999: 116-119.) Monissa tutkimuksissa keskiössä ovat virheellisyydet ja norminvastaisuudet, ja tutkimusmetodina on usein virheanalyysi. Pelkkä virheiden tarkastelu ei kuitenkaan anna koko kuvaa oppijan kielestä, vaan tulisi myös nostaa esiin se, mitä oppija jo hallitsee (Ellis \& Barkhuizen 2005: 73). Kontrastiivisen metodin avulla tutkijat analysoivat lähdekielen ja kohdekielen samuuksia, eroja ja vaikutusta (esim. Kaivapalu 2005), jotka ovat tärkeitä tekijöitä oppijankielessä. 


\section{Aineisto ja sen käsittely}

Aineistonani on osa Ruotsin osakorpusta, joka sisältyy Kansainvälisen oppijansuomen korpukseen (International Corpus of Learner Finnish, ICLFI; Jantunen 2011: 86-105). Autenttiset tekstit on kerätty 2006-2009, ja ne sisältävät 43496 sanetta. Tekstit edustavat useita tekstityyppejä kuten kertomuksia, kuvauksia, kortteja, tekstin jatkamista ja sarjakuvan puhekuplien tekstejä. Kirjoitelmien aiheet liittyvät oppikirjana käytetyn Suomen kielen alkeisoppikirjan (Lepäsmaa \& Silfverberg 1998; 2009) teksteihin. Taitotasoltaan tekstit kuuluvat alkeistasolle, mikä ICLFIkorpuksen määritelmän mukaan tarkoittaa sitä, että oppijoiden saama kontaktiopetustuntimäärä on alle 200 tuntia (Jantunen 2011: 96).

Osakorpuksessa on yhteensä 4408 paikallissijaista sanetta, joista norminmukaisia esiintymiä on 4088 (93\%) ja norminvastaisia 320 (7 \%). (Määttä 2011: 167-168.) Esiintymät on jaettu ryhmiin funktioryhmän koon mukaan, jolloin erottuu neljä laajempaa kokonaisuutta: paikka, aika, verbin täydennykset (rektiot) ja muut. Ryhmässä "Muut" ovat absoluuttisilta määriltään vähäisemmät tapaukset. Hienojakoisempi ryhmittely olisi pirstonut aineiston käsittelyn. Rektiotapauksien lukumääristä huomautettakoon, että niihin eivät sisälly paikkaa ilmaisevat täydennykset (Hän menee kahvilaan.), vaan ne ovat ryhmässä Paikka.

Aineisto on analysoitu WordSmith Tools -ohjelmaan sisältyvällä konkordanssiohjelmalla, jonka avulla on saatu 4408 paikallissijassa esiintyvää sanetta. Funktioiden esille saamiseksi aineisto on analysoitu manuaalisesti, ja funktioiden määrittäminen ja jako pohjautuvat ISK:n (2004: 1187-1206) esittelemiin tapauksiin. Koneellinen analyysi ei ole ollut vielä mahdollista, koska ICLFI-korpusta ei ole annotoitu virhetyyppien mukaan. 


\section{Paikallissijaisten saneiden funktiot}

Oppijansuomen tutkimuksissa on todettu, että oppijoiden kirjallisissa tuotoksissa paikallissijaisia saneita esiintyy tiheään (esim. Lauranto 1997; Siivelt 2012), yleisemmin sisäpaikallissijoissa kuin ulkopaikallissijoissa (Määttä 2011: 168; Ampula 2002: 47). Tässä suhteessa oppijankieli muistuttaa suomen yleiskieltä (ISK 2004: 1179).

Paikallissijaiset saneet ovat frekventtejä, ja niillä on hyvin moninaisia tehtäviä ilmauksissa, lauseissa ja virkkeissä. Saneiden funktiot voivat olla konkreettisia tai abstrakteja. Nimensä mukaisesti paikallissijat ilmaisevat tyypillisesti paikkoja, paikkaan menemistä, paikassa olemista ja paikasta tulemista (sisäpuolella, ulkopuolella, jonkinlaisella pinnalla olemista). Niillä ilmaistaan myös muun muassa kokonaisuuden osia ja osien ominaisuuksia ja mentaalista ja fyysistä tilaa. Lisäksi paikallissijaisia saneita esiintyy temporaalisissa ilmauksissa, omistusrakenteissa ja tuloslauseissa. (ISK 2004: 1187-1206.) Ne ovat yleisiä myös verbien täydennyksinä.

Tässä paikallissijaisten saneiden funktioiden tarkastelussa aineisto on jaettu neljään ryhmään: 1. paikka, 2. aika, 3. rektio ja 4. muut. Hienojakoisempi ryhmittely olisi synnyttänyt koko joukon ryhmiä, joihin olisi kuulunut vain muutama esiintymä. Sellaiset tapaukset esitellään ryhmässä Muut. Taulukossa 1 esitetään, miten koko 4408 paikallissijaisen saneen aineisto jakautuu sijoittain ja funktioittain. Lukumäärät sisältävät sekä norminmukaiset että norminvastaiset esiintymät.

Ruotsinkieliset oppijat käyttävät paikallissijaisia saneita eniten paikan funktiossa $(67 \%)$. On todettu, että oppijankielessä tällainen paikallissijojen käyttö opitaan ensin. Martin ym. (2010: 65) toteavat paikan ilmaisujen olevan tyypillisimpiä oppijansuomessa A1-tasolla, mutta niiden käyttö vähenee taitotasolta toiselle C2-tasolle saakka. Toiseksi eniten $(13,4 \%)$ on ryhmän Muut tapauksia. Esiintymien korkeaan lukumäärään vaikuttaa se, että tuotoksissa käytetään paljon omistusrakenteita ja ilmaisuja, joiden osana on jokin välinettä tarkoittava adessiivimuotoinen sane. 
TAulukко 1. Paikallissijaisten saneiden funktiot

\begin{tabular}{|l|c|c|c|c|c|c|c|c|c|c|}
\hline \multirow{2}{*}{ sija } & \multicolumn{2}{|c|}{ paikka } & \multicolumn{2}{c|}{ aika } & \multicolumn{2}{c|}{ rektio } & \multicolumn{2}{c|}{ muut } & \multicolumn{2}{c|}{ summa } \\
\cline { 2 - 12 } & f & \% & f & \% & f & \% & f & \% & f & \% \\
\hline illatiivi & 1015 & 85,7 & 27 & 2,3 & 61 & 5,2 & 81 & 6,8 & 1184 & 26,9 \\
\hline inessiivi & 1265 & 90,8 & 45 & 3,2 & - & - & 83 & 6,0 & 1393 & 31,6 \\
\hline elatiivi & 176 & 50,3 & 6 & 1,7 & 127 & 36,3 & 41 & 11,7 & 350 & 7,9 \\
\hline allatiivi & 223 & 42,8 & - & - & 249 & 47,8 & 49 & 9,4 & 521 & 11,8 \\
\hline adessiivi & 244 & 28,3 & 273 & 31,7 & 8 & 0,9 & 336 & 39,0 & 861 & 19,5 \\
\hline ablatiivi & 31 & 31,3 & 13 & 13,1 & 52 & 52,5 & 3 & 3,0 & 99 & 2,3 \\
\hline summa & 2954 & 67,0 & 364 & 8,3 & 497 & 11,3 & 593 & 13,4 & 4408 & 100 \\
\hline
\end{tabular}

Taulukon 1 mukaan 11,3\% paikallissijaisten saneiden funktiona on toimia verbin täydennyksenä. Myös temporaalinen käyttö on runsaanlaista $(8,3 \%)$, ja se ilmenee useimmiten vuorokaudenaikojen ilmauksissa. Varis (2010: 24-25) on tutkinut Cefling-hankkeen koululaisaineiston ajanilmauksia taitotasoilla A1-B2, ja hänen aineistossaan (26063 sanetta) temporaalisten esiintymien osuus on $7,3 \%$. Variksen tuloksessa on huomionarvoista se, että ajanilmaukset ovat A1-tasolla tavallisempia kuin B2-tasolla.

Seuraavassa siirryn analysoimaan lähemmin paikallissijaisten saneiden käyttöä funktioittain. Esittelen, mitä paikallissijoja funktioissa käytetään, ja havainnollistan niiden käyttöä esimerkein.

\subsection{Paikan funktio}

Tarkasteltaessa paikallissijojen keskinäistä esiintymistä paikan funktiossa nähdään, että useimmissa tapauksissa käytetään inessiiviä (90,8 \%). Siivelt (2012: 30) on tutkinut vironkielisten oppijoiden sisäpaikallissijojen käyttöä ja funktioita, ja hänen mukaansa juuri inessiivi on tiheimmin esiintyvä sisäpaikallissija A2-tason teksteissä ilmaistaessa konkreettisia paikkoja (vrt. Martin ym. 2010: 65). Näyttäisi siltä, ettei inessiivin hallinnassa ja käytössä konkreettisen paikan funktiossa oppijan lähdekielellä ole vaikutusta. Sijamuotonakin inessiivi on frekventti 
niin oppijansuomessa (ks. esim. Ampula 2002; Siivelt 2010; Määttä 2011: 168) kuin yleiskielessäkin (ISK 2004: 1179). Esimerkit (1-3) ovat näytteitä norminmukaisista inessiivisistä paikan funktioista.

(1) Minä asuan loistohotellissa.

(2) Haluan kalasta ja uida merissä.

(3) Erään taukotuvan ikkunassa oli kolme kärpästä.

Inessiivimuodon tuottaminen ja käyttö paikan funktiossa hallitaan hyvin, varsinkin sellaisissa sanoissa, joiden taivutusvartalo on sama kuin nominatiivimuoto (hotelli, ikkuna). Taivutusvartaloissa, joissa tapahtuu muutoksia, ilmenee joskus norminvastaisuutta. Esimerkissä (2) oppija on tuottanut monikollisen inessiivimuodon merissä. Jää epäselväksi, onko oppija tarkoittanut uivansa useissa merissä vai onko kyseessä merisanan virheellinen taivutusvartalo meri- (po. mere-). Lauranto (1997: 165-166) on todennut, että "agglutinatiivisuus on ominainen piirre kielenoppimisjatkumon alkuvaiheille, joskin myöhemminkin. Morfofonologisia vartalonmuutossääntöjä ei kyetä vielä noudattamaan, niitä ei ehkä ole vielä edes opittu."

Myös illatiivia käytetään konkreettisten paikkojen funktiossa taajaan $(85,7 \%)$; sen perusmerkityshän on johonkin paikkaan siirtyminen tai meneminen. Illatiivi on toiseksi yleisin paikallissija ruotsinkielisten oppijoiden tuotoksissa (Määttä 2011: 168-169), ja saman tuloksen on saanut Ampula (2002) islantilaisten oppijoiden kirjoitelmista. Tulokset vastaavat suomen yleiskielen sijamuotojen yleisyyksiä (ISK 2004: 1179). Illatiivitapauksissa verbinä on usein jokin liikeverbi, mennä, lähteä tai tulla. Esimerkeissä (4-9) paikan funktion yhteydessä esiintyy muitakin liikeverbejä.

(4) Ruoan jälkeen minä lähdin parturiin.

(5) Perjantaina mennen teatteriin.

(6) Nähdään kun tulet kotiin.

(7) Eilen kävelimme museoon.

(8) Sitten ajan pyörällä työhön.

(9) Vien teekupin astianpesukoneeseen. 
Suurimmassa osassa paikan funktiossa esiintyvistä illatiivisista saneista illatiivin päätteenä on $V n$. Opintojen alussa oppijoiden sanasto ei ole suuri ja sanat ovat yleensä sellaisia, joiden taivuttaminen ei vaadi muuta kuin oikean illatiivipäätteen valinnan. Yksitavuisia sanoja, joiden illatiivi muodostetaan $h V n$-päätteellä, esiintyy oppijoiden teksteissä vähän. Frekventein sana on työ, ja yleisimmin se esiintyy fraasissa mennä työhön. Illatiivin seen-päätettä oppijat käyttävät eniten huone-sanan yhteydessä.

Jostakin paikasta pois tulemista ja pois siirtymistä kuvatessaan oppijat käyttävät elatiivia hyvin norminmukaisesti (ks. 4.1.). Elatiivisia paikan funktioita aineistossa on 50,3\%. Esimerkeissä (10-13) paikan funktion yhteydessä esiintyy jokin muu verbi kuin liikeverbi, jotka kuitenkin ovat tavallisimpia.

(10) --- otan leipä kaapista.

(11) Liisa sanoi että hän on Turusta ---.

(12) Mä lainasin kirjastosta yhden kirjan.

(13) Terveisiä Prahasta!

Neljänneksi eniten $(42,8 \%)$ paikan funktioissa käytetään allatiivia. Illatiivin tapaan se ilmaisee johonkin paikkaan menemistä, ja virkkeiden verbit ovat liikeverbejä. Samoin kuin adessiivitapauksissa, paikkaa ilmaiseva sana on näissä tapauksissa usein sellainen, jota (sijainnin merkityksessä) käytetään lähinnä ulkopaikallissijoissa. Esimerkeissä (14-17) oppijat käyttävät oikeaoppisesti allatiivia paikan funktioissa.

(14) Kun he tulevat mökille, melu alkaa.

(15) --- hän pyörtyy ja jysähtää lattialle.

(16) --- menin bussilla junaasemalle.

(17) Me lähdimme venellä merelle ---.

Paikan funktiota ilmaisevissa saneissa myös adessiivi on tavallinen $(28,3 \%)$, useimmiten adverbiaalina määrittämässä lauseessa kuvatun toiminnan tapahtumapaikkaa. Esimerkeissä (18-21) adessiivin valinta selittyy sen perusteella, että paikkana on (kolmiulotteisen esineen) ulkopinta, mutta oppijat käyttävät myös adessiivimuotoja sanoista, 
joita sijainnin merkityksessä yleensä taivutetaan vain ulkopaikallissijoissa (22).

(18) Sitten illalla istumme sohvalla ja katsomme televisiota.

(19) Siellä uin meressä ja nukin rannalla kuumassa auringossa.

(20) Kalle ja Liisa nukahtavat takaistuimella.

(21) Hiihdin valaistulla ladulla Suomessa.

(22) Jotkut ovat olleet ulkomailla joululle.

Ablatiivia käytetään paikan funktiossa lukumärällisesti kaikkein vähiten (31 esiintymää, 31,3\%). Tulos on odotuksenmukainen, sillä ablatiivi on kaikista paikallissijoista muutenkin vähiten esiintyvä ruotsinkielisillä oppijoilla (Määttä 2011: 168-169). Ablatiiviset paikan funktiot esiintyvät liikeverbien ja muidenkin verbien kanssa (23-26).

(23) Haluaisin talon järven rannalta.

(24) Asemalta menemme kotiini.

(25) Kun palasin kaupungilta päätin pelata vähän.

(26) Hän oti kynäsi korvalta.

Oppijat käyttävät kaikkia paikallissijoja ilmaistessaan paikan funktiota. Sijamuodon muodostaminen hallitaan hyvin, ja myös astevaihtelun alaiset sanat ovat oikein kirjoitettuja. Suurimmassa osassa paikan funktioista myös tekemisen suunta ja tilan sisäisyys tai ulkoisuus on ymmärretty oikein (vrt. 4.2.).

\subsection{Ajan funktio}

Suurin osa paikallissijaisista temporaalisista funktioista ilmaistaan adessiivilla (31,7 \%). Frekventeimmät ilmaukset ovat aamulla ja illalla (2728). Vuodenajoista mainitaan yleisimmin talvi; kesä esiintyy vain kerran (29-30). Oppijat käyttävät ilmausta viikolla, ja sillä on usein määritteenä ensi ja viime (31-32).

(27) Aloitin jo kahdeksalta aamulla.

(28) Illalla käytän tietokonetta.

(29) Talvella matkustaisin Floridaan. 
(30) Kesälla kutsuisin talolle koko perheen ---.

(31) He tarvitsi henkilökuntaa ensi viikolla.

(32) Viime viikkolla olin Zanzibarilla.

Ablatiivisilla ajanilmauksilla oppijat kertovat kellonajan, jolloin jotakin tapahtuu (33-34). Esiintymiä on kuitenkin vähän, mikä johtunee siitä, että opintojen alkuvaiheessa kellonajat ilmaistaan käyttäen kello-sanaa ja numeroa, esimerkiksi Lähden kotiin kello viisi. Aineistossa on kaksi esiintymää, joissa sana luku on ablatiivimuotoinen vuosiluvun yhteydessä (35).

(33) Ajaisin Uumajaan maanantaina kolmelta.

(34) Timo heräsi kuudelta ---.

(35) --- kaunita tauloja uodesta 1500-luvulta ja eteenpäin. --- mielenkiintoisen kellotornin 1500-luvulta.

Sisäpaikallissijoista ajanilmauksissa käytetään eniten inessiiviä $(3,2 \%)$, useimmiten kuukausien nimissä (36-37). Illatiivimuotoisten ajanilmauksien kohdalla (38-40) on kyse kellonajasta, johon asti joku tekee jotakin. Esiintymissä mainitaan pelkkä kellonaika tai kellonaika yhdessä postposition asti kanssa. Myös ilmauksista myöhään, pitkään ja pitkään aikaan on esiintymiä. Elatiivisia ajanilmauksia aineistossa on vain kuusi (41).

(36) --- kunnon talvi tulee joskus helmikuussa.

(37) Mirkulla ja minulla on loma heinäkuussa.

(38) Opiskelen kello kuuteen ---.

(39) Perhe Virtanen herätään myöhään.

(40) En ole käynyt pitkään aikaan.

(41) --- ruoho on niin märkeää aamusta ---.

Ajan funktioissa oppijat käyttävät adessiivia, ablatiivia, inessiiviä, illatiivia ja elatiivia. Tavallisin ajanilmaus on adessiivinen vuorokaudenajan ilmaus. Toiseksi yleisin sija on inessiivi, joka esiintyy kuukausien nimissä. Sen sijaan ablatiiviset, illatiiviset ja varsinkin elatiiviset ajanilmaukset eivät ole kovin taajaan käytettyjä oppijoiden teksteissä. 


\subsection{Verbin rektio}

Paikallissijaisia verbin täydennyksiä on $11,3 \%$. Yleisimmät sijat ovat allatiivi (47,8 \%) ja elatiivi (36,3\%). Allatiivisten rektioiden verbeinä on suurimmassa osassa soittaa, antaa, ostaa tai sanoa (42-45). Elatiivisen täydennyksen (46-48) puolestaan saavat useimmiten verbit pitää ja nauttia. Pitää-verbin rinnalla käytetään myös arkityylisempää tykätäverbiä. Elatiivisten täydennysten joukko on yleisesti ottaen hyvin heterogeeninen.

(42) Sen jälkeen soitin kaverille.

(43) Hän antaa Timolle Kaisan puhelinnumeron.

(44) Ostaisin uudet autot minulle, äidille ja isälle.

(45) Sano terveisiä kaikille.

(46) Minä en pidä kahvista.

(47) Me nautimme ilmasta.

(48) Timo ei tykännyt kiinalaisesta ruuasta.

Myös illatiivia ja ablatiivia käytetään verbien täydennyksissä. Illatiivin kohdalla yleisimmät verbit ovat ihastua, tutustua ja vastata (49-51). Ihastua ja tutustua lienevät frekventtejä siksi, että aineistossa on kirjoitustehtävä, jossa ihastuminen ja tutustuminen toiseen henkilöön ovat keskiössä. Se, että jotkin sanat dominoivat jossakin tekstissä, on siis yhteydessä tekstityyppiin (Määttä 2012: 207-210). Vastata-verbin taajaan käyttöön vaikuttaa teksteissä toistuva ilmaus vastata puhelimeen. Ablatiiviset täydennykset esiintyvät yleisimmin verbin kysyä kanssa. Myös aistiverbeistä tuntua, näyttää ja kuulostaa on useita esiintymiä (53-55).

(49) Kerttu ihastuu kauniisiin vanhoihin taloihin.

(50) Kaisa vastasi puhelimeen.

(51) Haluan tutustua häneen.

(52) Seuraavaksi Timo kysyy Kaisalta jos hänellä on poikaystävä.

(53) Tuntuu ihan kivalta!

(54) Hän näyttää eteläeuroppalaiselta.

(55) Mieleläni, se kuulosta hirveän mukavalta! 
Taulukossa 1 on adessiivin kohdalla rektiosarakkeessa kahdeksan esiintymää. Kaikki esiintymät ovat norminvastaisia. Oppijat ovat käyttäneet adessiivia verbin täydennyksissä, vaikka niissä kuuluisi käyttää jotakin muuta sijamuotoa (ks. 4.2.).

\subsection{Muut-ryhmän funktiot}

Ryhmässä Muut adessiivin yliedustus (39 \%) erottuu selvästi. Yksi syy korkeaan lukumäärään on omistuslauseiden sijoitus tähän ryhmään. Niitä on kaikkiaan 141 kappaletta (Määttä 2011: 167). Toinen adessiivin suurtaajuinen funktio on jonkin välineen funktio. Tällaisia esiintymiä on 111, ja yleisimpiä ovat kulkuvälineellä liikkumisen kuvaukset. Oppijat ilmaisevat adessiivin avulla myös tekemisen tapaa ja tunnetiloja.

(56) Timo ajatteli että elinalla oli nätit hampaat ---. (omistusrakenne)

(57) Minä menin bussilla torille. (väline)

(58) Timo mieti elämäänsä oikein kunnolla illan aikana. (tapa)

(59) Timo istui ravintolassa ja oli huonolla tuulella. (tunnetila)

Oppijat ilmaisevat henkilöiden mielipiteitä siten, että mielipiteen ilmaisija on elatiivimuotoinen (60-61). Vaihtoehtoisia ilmaisuja kuten minun mielestäni, hänen mielestään, ei esiinny lainkaan.

(60) Jää on mustaa ja minusta vaarallista.

(61) Meistä filmin on hyvä.

Usein kuvataan menoa aterialle tai vastaavaan tilanteeseen tai sellaisessa olemista (62-65). ISK:n (2004: 1195-1196) mukaan ulkopaikallissijoja käytetään muun muassa nautittaessa jostakin, ja esimerkkeinä ovat juuri aterioille meneminen tai niillä oleminen. Sijoina ovat allatiivi ja adessiivi. Ablatiivimuotoisia aterioilta tai vastaavilta pois lähtemistä, tulemista tai menemistä ei esiinny.

(62) Olemme kutsuneet ystävät illalliselle tänä iltana.

(63) Viimeisenä iltana lähdemme oluelle.

(64) Karin tuli päivällä kahville.

(65) Syön usein puuroa aamiaisella. 
Oppijat kuvailevat joskus tilaisuuksiin tai vastaaviin menemistään (6668). Yleisintä on meno jonkinlaiseen juhlaan (juhla-sana yksikössä), ja käytetyin sija on illatiivi. Sen rinnalla esiintyy myös allatiivi sanoissa, jotka vaativat ulkopaikallissijan käyttöä (oppitunti, kurssi, luento). Tilaisuudessa tai vastaavassa olemisesta käytetään aineistossa inessiivisiä ja adessiivisia ilmauksia (69-70).

(66) Illalla menen juhlaan kaverin luo.

(67) Tarvitsin mennä jonnekin kokoukseen.

(68) Menen luennolle.

(69) Kello yksitoista kävin yogassa Iksu:ssa.

(70) Olin oppitunteilla aamupäivän.

Edellä esiteltyjen funktioryhmien pohjalta voi todeta ruotsinkielisten oppijoiden käyttävän jo alkeistasolla paikallissijoja niin konkreettisissa kuin abstrakteissakin funktioissa varsin runsaasti. Konkreettisen paikan funktio on yleisin. Huomionarvoista on se, että oppijoiden teksteissä on jo tässä vaiheessa paljon rektioverbejä. Todennäköisimmin tähän vaikuttaa oppikirjan sanasto.

\section{Norminmukaiset ja norminvastaiset paikallissijaiset saneet eri funktioissa}

Tutkimusten mukaan suomen kolmijakoinen paikallissijasysteemi ero-, olo- ja tulosijoineen (esim. Lähdemäki 1995: 91; Manninen \& Martin 2000: 88) tai yleisemmin tapa, jolla suomen kielessä kuvataan tilaa (Ingo 2000: 277), aiheuttavat ongelmia ruotsinkielisille oppijoille. Ingo (2000: 273) on todennut länsieurooppalaisten kielten kiinnittävän vähän huomiota paikallisuuden laatuun ja liikkeen suuntaan. Jos oppijan lähdekielessä liikkumista ja tilaa kuvataan eri tavalla (ruotsissa prepositioita käyttäen) kuin kohdekielessä (suomessa paikallissijoin), oikean sijan valinta kaikkiin yhteyksiin voi olla vaikeaa.

Paikallissijaisten saneiden funktioiden tarkastelusta ilmenee kuitenkin, että ruotsinkieliset oppijat ovat onnistuneet hyvin valitsemaan 
oikean paikallissijan tarvitsemaansa funktioon. Taulukossa 2 on funktioittain norminmukaisten ja norminvastaisten paikallissijaisten saneiden esiintymät.

TAulukко 2. Paikallissijaisten saneiden norminmukaiset ja norminvastaiset esiintymät funktioittain

\begin{tabular}{|l|c|c|c|c|c|c|}
\hline \multirow{2}{*}{ funktio } & \multicolumn{2}{|c|}{ norminmukainen } & \multicolumn{2}{c|}{ norminvastainen } & \multicolumn{2}{c|}{ summa } \\
\cline { 2 - 7 } & $\mathbf{f}$ & $\mathbf{\%}$ & $\mathbf{f}$ & $\mathbf{\%}$ & f & \% \\
\hline paikka & 2725 & 92,2 & 229 & 7,8 & 2954 & 67,0 \\
\hline aika & 337 & 92,6 & 27 & 7,4 & 364 & 8,3 \\
\hline rektio & 483 & 97,2 & 14 & 2,8 & 497 & 11,3 \\
\hline muu & 543 & 91,6 & 50 & 8,4 & 593 & 13,4 \\
\hline summa & 4088 & 92,7 & 320 & 7,3 & 4408 & 100 \\
\hline
\end{tabular}

Keskimäärin $93 \%$ funktioiden paikallissijaisista saneista on norminmukaisia, mikä osoittaa, että suomen paikallissijojen perusmerkitykset ja -käytöt ovat omaksuttavissa jo alkeistasolla. Norminvastaisten esiintymien määrä (7\%) ei tunnu kovinkaan korkealta, kun vertaa siihen, että esimerkiksi islanninkielisillä oppijoilla vastaava osuus voi olla $15 \%$ (Ampula 2002: 46).

\subsection{Norminmukaiset paikallissijaiset saneet eri funktioissa}

Kaikista (4 408) paikallissijaisten saneiden funktioiden esiintymistä suurin osa (4 088) on norminmukaisia. Tarkasteltaessa saneiden funktioiden jakaumaa paikallissijoittain nähdään, että konkreettisten ja abstraktien funktioiden lukumäärät vaihtelevat paljon. Taulukosta 3 on myös luettavissa, että joitakin paikallissijoja ei käytetä kaikissa mahdollisissa funktioissa. 
TAULUкко 3. Norminmukaisten paikallissijaisten saneiden funktiot sijoittain

\begin{tabular}{|l|c|c|c|c|c|c|c|c|c|c|}
\hline \multirow{2}{*}{ sija } & \multicolumn{2}{|c|}{ paikka } & \multicolumn{2}{c|}{ aika } & \multicolumn{2}{c|}{ rektio } & \multicolumn{2}{c|}{ muut } & \multicolumn{2}{c|}{ summa } \\
\cline { 2 - 12 } & $\mathbf{f}$ & $\mathbf{\%}$ & $\mathbf{f}$ & $\mathbf{\%}$ & $\mathbf{f}$ & $\mathbf{\%}$ & $\mathbf{f}$ & $\mathbf{\%}$ & $\mathbf{f}$ & $\mathbf{\%}$ \\
\hline illatiivi & 973 & 85,6 & 27 & 2,4 & 61 & 5,7 & 76 & 6,7 & 1137 & 27,8 \\
\hline inessiivi & 1191 & 92,6 & 36 & 2,8 & - & - & 59 & 4,6 & 1286 & 31,5 \\
\hline elatiivi & 173 & 51,3 & 5 & 1,5 & 124 & 36,8 & 35 & 10,4 & 337 & 8,2 \\
\hline allatiivi & 165 & 36,0 & - & - & 248 & 54,0 & 46 & 10,0 & 459 & 11,2 \\
\hline ghtadessiivi & 198 & 25,4 & 256 & 32,8 & - & - & 326 & 41,8 & 780 & 19,1 \\
\hline ablatiivi & 25 & 28,1 & 13 & 14,6 & 50 & 56,2 & 1 & 1,1 & 89 & 2,2 \\
\hline summa & 2725 & 66,7 & 337 & 8,2 & 483 & 11,8 & 543 & 13,3 & 4088 & 100 \\
\hline
\end{tabular}

Sisäpaikallissijat illatiivi, inessiivi ja elatiivi dominoivat konkreettisen paikan funktiossa. Siiveltin (2012: 30-31, 39-40, 49) vironkielisten oppijoiden teksteissä illatiivilla ilmaistuja paikan funktioita ei ole lainkaan A1-tasolla, vaan ne ilmestyvät teksteihin vasta A2-tasolla. Tulosta Siivelt (2012) selittää illatiivin morfologisella kompleksisuudella, ja hän toteaa myös tehtävätyypin saattaneen vaikuttaa. Sitä vastoin vironkielisillä esiintyy inessiivisiä ja elatiivisia paikan funktioita kaikilla taitotasoilla. Elatiivisten norminmukaisten konkreettisten paikan funktioiden esiintyminen on enimmillään A1-tasolla, ja näiden osuus on yli $80 \%$. Sisäpaikallissijaiset abstraktit ajan funktiot eivät ole frekventtejä ruotsinkielisten oppijoiden teksteissä. Sitä vastoin illatiivia ja elatiivia käytetään verbin täydennyksissä jo runsaammin.

Ulkopaikallissijoista allatiivi ja ablatiivi esiintyvät eniten (yli 50 \%) verbien täydennyksissä. Noin 1/3 ulkopaikallissijaisista saneista ilmaisee paikan funktiota. Ajan funktiossa adessiivi ylikorostuu, kun taas allatiivista ei ole esiintymiä.

Ryhmään Muut kuuluvat funktiot ovat enimmäkseen norminmukaisia (vrt. taulukko 4). Adessiivin korkea lukumäärällinen ja prosentuaalinen osuus johtuu siitä, että ryhmä sisältää lukuisia eri funktioita, joista suurimman ryhmän muodostavat omistuslauseet ja kulkuvälineiden ilmaukset. 


\subsection{Norminvastaiset paikallissijaiset saneet eri funktioissa}

Ruotsinkielisten oppijoiden teksteissä kaikki sijavalinnat eri funktioissa eivät ole johtaneet oikean paikallissijan käyttöön kontekstin vaatimalla tavalla. Aineistossa on 320 tapausta, joissa valitun paikallissijan asemesta tulisi käyttää muuta paikallissijaa tai muuta sijamuotoa. Taulukko 4 näyttää, missä määrin paikallissijat esiintyvät norminvastaisesti eri funktioissa.

TAULuкко 4. Norminvastaisten paikallissijaisten saneiden funktiot sijoittain

\begin{tabular}{|l|c|c|c|c|c|c|c|c|c|c|}
\hline \multirow{2}{*}{ sija } & \multicolumn{2}{|c|}{ paikka } & \multicolumn{2}{c|}{ aika } & \multicolumn{2}{c|}{ rektio } & \multicolumn{2}{c|}{ muut } & \multicolumn{2}{c|}{ summa } \\
\cline { 2 - 12 } & f & $\mathbf{\%}$ & f & $\mathbf{\%}$ & f & \% & f & \% & f & $\%$ \\
\hline illatiivi & 42 & 89,4 & - & - & - & - & 5 & 10,6 & 47 & 14,7 \\
\hline inessiivi & 74 & 69,2 & 9 & 8,4 & - & - & 24 & 22,4 & 107 & 33,4 \\
\hline elatiivi & 3 & 23,1 & 1 & 7,7 & 3 & 23,1 & 6 & 46,1 & 13 & 4,1 \\
\hline allatiivi & 58 & 93,6 & - & - & 1 & 1,6 & 3 & 4,8 & 62 & 19,4 \\
\hline adessiivi & 46 & 56,8 & 17 & 21,0 & 8 & 9,9 & 10 & 12,8 & 81 & 25,3 \\
\hline ablatiivi & 6 & 60,0 & - & - & 2 & 20,0 & 2 & 20,0 & 10 & 3,1 \\
\hline summa & 229 & 71,6 & 27 & 8,4 & 14 & 4,4 & 50 & 15,6 & 320 & 100 \\
\hline
\end{tabular}

Suurin osa (noin $72 \%$ ) virheellisistä paikallissijavalinnoista esiintyy paikan ilmauksissa. Allatiivia käytetään virheellisesti eniten, ja sen jälkeen illatiivia. Määttä (2010: 101-126) on kartoittanut näiden kahden sijamuodon käyttöä ja vaihtelua keskenään (71-72). Sijojen käyttö on horjuvaa, mihin vaikuttanee ruotsin ja suomen erilainen toiminnan tapahtumasuunnan ja tilakäsityksen mieltäminen. Toisena mahdollisena syynä illatiivin ja allatiivin sekoittumiseen Määttä (2010) esittää sanastollista vaikutusta. Oppijat totutetaan muun muassa oppimateriaalin välityksellä sisäpaikallissijoissa taipuviin sanoihin. Oppikirjoissa on niukalti ulkopaikallissijoissa taipuvaa sanastoa, mikä voi vaikeuttaa ja hämärtää oppijoiden kykyä käyttää näitä sijoja oikealla tavalla oikeissa konteksteissa. 
(71) Sitten minä menin asemaan. (asemalle)

(72) Ja muuttaisin toinen asunnolle. (asuntoon)

Esimerkeissä (71) ja (72) tekemisen suunta, johonkin meneminen, on aivan oikein. Sitä vastoin tekemisen paikan sisäisyys ja ulkoisuus on tuottanut ongelman ja johtanut väärään sijavalintaan.

Temporaalisen funktion ilmaiseminen näyttää olevan oppijoille paljon helpompaa kuin paikan funktioiden. Tuotoksissa on kuitenkin esiintymiä, joissa inessiiviä, elatiivia ja varsinkin adessiivia on käytetty norminvastaisesti. Inessiiviset ajanilmaukset vaihtelevat suuresti keskenään. Esimerkissä (73) oppijalla on inessiivi adessiivin asemesta. Lauseen ruotsinnoksessa, Jag åt en hamburgare vid midnatt, on prepositio vid, jonka vastine suomessa ei ole inessiivi, vaan vain adessiivi ja ablatiivi ovat mahdollisia. Esimerkin (74) inessiivimuodossa lienee ruotsin vaikutusta $i$-preposition välityksellä (Jag var och promenerade $i$ skogen i två timmar.). Sekä lukusana että sen pääsana ovat inessiivissä, vaikka lukusanan tulisi olla nominatiivissa ja pääsanan partitiivissa. Myös esimerkissä (76) inessiivin valinta johtunee ruotsin $i$-prepositiosta (I pausen dricker man kaffe.). Teksteissä on ajan funktioiden joukossa myös tiettyä ajankohtaa ilmoittavia esiintymiä. Tällaisissa tapauksissa oppija on joskus käyttänyt inessiiviä essiivin asemesta (75).

(73) Söin hampurilaisen keskiyössä. (keskiyöllä)

(74) Olin kävelemässä metsässä kahdessa tunnissa. (kaksi tuntia)

(75) Nähdään Närpiössä joulussa. (jouluna)

(76) Taukossa juodan kahvia. (tauolla)

Kuuden ajanilmauksen (ks. taulukko 1) sijana on elatiivi. Vain yksi esiintymä on norminvastainen (77). Lauseen predikaattina on rektioverbi säästää, jonka täydennys voi esiintyä illatiivissa, allatiivissa ja inessiivissä (Jönsson-Korhola \& White 1997: 130). Elatiivin käytön taustalla ei liene ruotsin vaikutusta, koska tässä tapauksessa ruotsissa on prepositio för, joka voi vastata illatiivia mutta myös muita sijoja (Jag skulle också spara för framtiden.). Verbin säästää täydennyksen kuuluu olla esimerkissä illatiivissa. 
(77) Myös säästäisin rahaa tulevaisuudesta. (tulevaisuuteen)

Adessiivimuotoisissa virheellisissä ajanilmauksissa adessiivia on käytetty essiivin sijasta. Monet essiivimuotoiset ajanilmaukset, kuten viikonpäivien käyttö, omaksutaan usein kokonaisina fraaseina, niitä analysoimatta. Näin on itse asiassa myös adessiivisten vuorokauden- ja vuodenaikojen ilmausten laita, mutta essiiviin, toisin kuin adessiiviin, ei muuten tutustuta alkeiskurssilla, eikä sen muodostukseen ja käyttöön puututa muuten kuin juuri viikonpäivien ja tietyn ajankohdan ilmaisemisen yhteydessä. Adessiiviset ajanilmaukset ovat sitä vastoin frekventtejä ja aktiivissa käytössä. Esimerkissä (78) lienee ruotsin på-preposition vaikutusta ( Vad ska vi äta på lördag?). Usein ajanilmauksella on määrite, ja oppijat taivuttavat myös sen kongruenssin mukaisesti adessiivissa (79).

(78) Mitä syömme lauantailla? (lauantaina)

(79) Tällä aamulla olin aika väsynyt. (tänä aamuna)

Norminvastaisten adessiivimuotoisten ajanilmausten joukossa on esiintymä, jossa on sekä essiivin että adessiivin pääte (80). Oppija on taivuttanut viikonpäivän oikeaoppisesti essiivissä mutta lisännyt vielä adessiivin päätteen. Tuntuu epätodennäköiseltä, että oppija olisi ajatellut muotoa tiistaina sanan perusmuotona, jota sitten voi taivuttaa sijoissa. Kahden sijapäätteen käyttö samassa sanassa on kuitenkin aineistossani harvinaista. Yhdessä ajanilmauksessa oppija on käyttänyt adessiivia inessiivin asemesta (81). Kyse on toiminnan toistuvuudesta jonakin aikana, ja tällaisissa tapauksissa ajanilmaus on inessiivissä (ISK 2004: 1198).

(80) Tiistainalla menen thainyrkkeily ---. (Tiistaina)

(81) Kaksi kertaa viikolla minä opiskelen suomea ---. (viikossa)

Norminvastaisen paikallissijan käyttö rektioverbin yhteydessä on oppijoilla yllättävän vähäistä siihen nähden, miten paljon suomi ja ruotsi rakenteellisesti eroavat toisistaan. Nissilä (2011: 199) on tutkinut vironkielisten suomenoppijoiden verbien ja niiden rektioiden oppimista ja toteaa, että mitä lähempänä lähtökielen järjestelmä on kohdekielen 
järjestelmää, sitä paremmin onnistutaan rektion tuottamisessa. Nissilän (2011: 212, 218) tuloksista näkyy myös, että rektioiden hyvään hallintaan vaikuttavat verbin frekvenssi ja opiskeluajan pituus.

Kahdeksan verbin täydennyksessä oppija on käyttänyt virheellisesti adessiivia. Sen asemesta niihin kuuluisi seitsemässä tapauksessa allatiivi (82) ja yhdessä illatiivi (83). Ranua ja Ruotsalainen (2007: 150-151) ovat tutkineet syntaktisia virheitä Suomessa suomea oppineiden ja suomea vieraana kielenä oppineiden kirjoitelmista. Kummankin ryhmän oppijat tekevät rektiovirheitä, joissa olosijan asemesta on käytetty tulosijaa (Ranua \& Ruotsalainen 2007: 162). Virheet ovat siis päinvastaisia verrattuna ruotsinkielisten oppijoiden tekemiin virheisiin. Oppijalla on kolmessa täydennyksessä elatiivi, joista kahdessa pitäisi olla ablatiivi ja yhdessä allatiivi (84-85). Myös allatiivisesta ja ablatiivisesta verbin täydennyksestä on virheelliset esiintymät (86-87). Ingo (2000: 295) on todennut rektioiden olevan sattumanvaraisia siinä missä muiden kielten prepositioiden käyttö vastaavissa ilmauksissa. Näin ollen oppijan on opeteltava muistamaan sanojen rektiot ulkoa, koska minkäänlaista säännöstöä ei ole tukena. Nissilä (2011: 107) viittaa työssään Koiviston (1994: 106) mainintaan, jonka mukaan äidinkielellä ja oppijan osaamilla muilla kielillä on paljon vaikutusta verbirektioiden oppimiseen.

(82) Eläinpuistossa Timo tarjoili Liisalla lounaksen. (Liisalle)

(83) Nyt hän täyty ottaa yhteys Kaisalla! (Kaisaan)

(84) Närheä hiljetä ja kysy Timosta, mitä on tapahtunut. (Timolta)

(85) Kerro terveisiä Timosta! (Timolle)

(86) --- antaisin rahaa niiten kirjoitus- ja taideprojektille. (taideprojektiin)

(87) - Närhi ei tiennyt niin paljon Kaisalta. (Kaisasta)

Esimerkeissä (84), (86) ja (87) verbin täydennyksissä suunta on oikea, mutta ongelman aiheuttaa ulkoisuuden ja sisäisyyden hahmottaminen. Ruotsissa on verbejä, joiden kanssa käytetään tiettyjä prepositioita kontekstista riippuen. Mainittakoon esimerkkinä verbi veta 'tietää, jonka kanssa esiintyy om-prepositio, kun merkityksenä on 'tietää jostakin'. 
Ryhmän Muut tapauksissa kaikkia paikallissijamuotoja on käytetty norminvastaisesti eri funktioissa. Illatiiviset muodot esiintyvät muun muassa tilaisuudeksi hahmotettavissa sanoissa kurssi ja luento (88-89). Oppija ei ole tiennyt tai muistanut, että sanat ovat ulkopaikallissijoissa taipuvia, tässä tapauksessa allatiivissa.

(88) --- viisitoista yli yksi menen seraavaan kursiin. (seuraavalle kurssille)

(89) --- sitten menen suomeen luentoon. (luennolle)

Paikallissijoja käytetään norminvastaisesti objektin (90-94) ja subjektin sijoina (95-96). Objektin sijoina kuuluisi olla partitiivi tai genetiivi. Esimerkissä (91) lienee ruotsin vaikutusta; lauseen ruotsinnos on Jag spelar inte på lotto, ja prepositio på vastaa suomessa inessiiviä ja adessiivia. Esimerkissä (92) oppija käyttää verbiä ajatella, jonka täydennys voi olla objektina partitiivissa tai adverbiaalina elatiivissa. Ruotsin vastaava verbi tänka esiintyy kahden preposition kanssa: tänka på 'ajatella jotakin/jotakuta', vastaa partitiivia, ja tänka om 'ajatella jostakin/jostakusta', vastaa elatiivia. Oppija on nähtävästi sekoittanut verbin rektiot.

(90) --- tekisin osa-aikatyössä. (osa-aikatyötä)

(91) En pelaa lottossa ---. (lottoa)

(92) Minä ajattelen Noorista ja hänen sulhasesta. (Nooria, sulhasta)

(93) Hän aikoi ryöstää pankilta ---. (pankin)

(94) Pian aikon menen katsomaan tempelilla. (temppeliä)

Subjekteissa oppijoilla on inessiivi nominatiivin asemesta. Oppikirjassa fraasi käydä suihkussa esitellään aikaisin, ja sitä toistetaan lukukappaleissa ja dialogeissa. Esimerkissä (95) suihku-sana on inessiivimuotoinen kuten se on käydä-verbinkin yhteydessä. Kyseinen lause on eksistentiaalilause, jossa yksiköllisten subjektien tulee olla nominatiivissa. Esimerkissä (96) on niin ikään subjektin sijana inessiivi nominatiivin asemesta.

(95) Talossa on keitoa, suihkussa ja kuusi sängyt. (keittiö, suihku, sänkyä)

(96) Pekingissä on suuri kaupunki. (Peking)

Joissakin lauseissa oppijoilla on prepositioita (97-98) ja postpositioita (99-100), joissa pääsana on paikallissijainen. Prepositiot ympäri ja 
pitkin vaativat kuitenkin partitiivia (Karlsson 2009: 279), postpositiot genetiiviä. Esimerkissä (98) oppijalla on partitiivi adjektiivissa pieni (virheellisesti pentä) mutta pääsana on adessiivissa. Oppija on ilmeisesti keskittynyt preposition sijasta ajattelemaan toiminnan paikkaa, "polulla kulkemista”, ja näin päätynyt adessiiviin.

(97) --- koiranäyttelyyn ympäri Ruotsissa asuntovaunussa. (Ruotsia)

(98) Me meni pitkin pentä polkulla. (polkua)

Postpositioidenkin yhteydessä oikean sijan valinta horjuu, vaikka alkeistasolla opiskelijat tutustuvat genetiiviä vaativiin postpositioihin. Lisävaikeuksia aiheuttavat kolmimuotoiset postpositiot, kuten taakse, takana, takaa, koska oppijan tulisi kiinnittää huomiota myös tekemisen suuntaan (99). Esimerkissä (100) postposition muoto on oikea mutta pääsana on adessiivissa vaadittavan genetiivin sijasta. Adessiivin käytön voisi tulkita niin, että oppijalla on ollut mielessään junalla matkustaminen.

(99) Hän piirti jotakin ruokasialle takana. (ruoka-astian taakse)

(100) Bussi lähtee junalla edestä. (junan)

\section{Lopuksi}

Tässä artikkelissa olen analysoinut ruotsinkielisten alkeistason suomenoppijoiden käyttämien paikallissijojen funktioita. Analysoitavana ovat olleet sekä norminmukaiset että norminvastaiset esiintymät. Halusin selvittää, mitkä funktiot ovat edustettuina oppijoiden teksteissä ja missä funktioissa ilmenee mahdollisia ongelmia. Olen myös pyrkinyt kuvaamaan, mistä mahdolliset ongelmat johtuvat.

Oppijat käyttävät paikallissijoja monissa funktioissa. Yleisimpiä ovat konkreettisen paikan ilmaisut, ja näissä ilmaisuissa on käytetty kaikkia paikallissijoja. Suurtaajuisimmat sijat ovat inessiivi ja illatiivi. Myös temporaalisen funktion ilmaisuja on runsaasti, ja adessiivi on yliedustettuna. Allatiivi on ainoa paikallissija, joka ei esiinny ollenkaan ajanilmauksissa. Huomionarvoista on se, että jo alkeistasolla kirjoitetuissa 
teksteissä esiintyy runsaasti rektioverbejä, joiden täydennyksen tulee olla paikallissijassa. Aineistossa esiintyy lisäksi muun muassa omistuslauseita, kulkuvälineiden käytön ilmaisuja, mielipiteen ilmaisuja sekä aterioihin ja erityyppisiin tilaisuuksiin liittyviä ilmaisuja.

Funktioissa esiintyvistä paikallissijaesiintymistä $93 \%$ on norminmukaisia ja $7 \%$ norminvastaisia. Tulos osoittaa, että oppijat hallitsevat hyvin eri funktioihin sopivan paikallissijan käytön. Norminvastaisissa tapauksissa on useimmiten kyse väärän paikallissijan valinnasta. Oppijat hahmottavat tekemisen suunnan mutta tilan ulkoisuus tai sisäisyys ei ole kaikissa funktioissa selvä. Esimerkiksi paikan funktiossa illatiivi ja allatiivi vaihtelevat keskenään. Tähän vaikuttanee se, että suomessa ja ruotsissa tilakäsitys hahmotetaan eri tavoin. Temporaalisessa funktiossa adessiivi dominoi virheellisenä sijana. Melkein kaikissa tapauksissa oppijan olisi tullut käyttää essiiviä, jonka muodostamiseen ja käyttöön alkeiskurssilla ei puututa. Adessiivin norminvastaista käyttöä ilmenee myös rektioverbien yhteydessä. Näissä tapauksissa allatiivi olisi ollut oikea sijavalinta. Teksteissä on sellaisiakin tapauksia, joissa oppija on käyttänyt paikallissijaa objektin ja subjektin sijana. Lisäksi on muutama esimerkki postposition ja preposition pääsanan paikallissijaisesta muodosta.

Saatujen tulosten mukaan oppijat kykenevät operoimaan paikallissijasysteemillä ja käyttämään sijoja vaihtelevissa funktioissa. Näyttää siltä, että sanojen muodot, merkitykset ja käyttö hahmotetaan suurimmaksi osaksi oikein. Opetuksessa on tavanomaista edetä konkreettisista paikan funktioista abstraktisimpiin funktioihin. Paikallissijoilla on useita abstrakteja funktioita, esimerkiksi verbin täydennykset, joihin voi jo alkeistason kursseilla paneutua tarkemmin. Tarkastelemalla funktioita eri konteksteissa oppija huomaa, kuinka sama sana taivutettuna eri paikallissijoissa saa eri merkitykset.

Edellä sanotusta käy ilmi, että jo alkeistasolla oppija kykenee varsin onnistuneesti ilmaisemaan eri funktioita paikallissijojen kautta. Esiteltäessä paikallissijat erikielisille oppijoille suomi vieraana kielenä -opetuksessa on ensiarvoisen tärkeää pohtia yhdessä oppijoiden kanssa, 
miten suomen suunta- ja tilakäsitys toimivat, koska kielten välillä on eroja. On myös tärkeää, että tutkimuksissa saaduista tuloksista kerrotaan oppijoille ja annetaan esimerkkejä piilevistä "vaaroista”.

Tämä paikallissijaisten saneiden funktioiden tutkimus on toinen osa laajempaa ruotsinkielisten suomenoppijoiden kirjallisten tuotosten paikallissijatutkimusta. Seuraavassa vaiheessa tutkimuksen kohteena ovat rektioverbit. Tutkimus on välttämätön ihan käytännön tarpeesta: tulosten pohjalta on mahdollista tuottaa opetus-, oppi- ja harjoitusmateriaalia, jota oppijat kipeästi tarvitsevat.

\section{Lähteet}

Ampula, Hanna 2002. Paikallissijat ja abessiivi islantilaisten suomenoppijoiden kirjoitelmissa. Julkaisematon suomen kielen pro gradu -tutkielma. Oulun yliopisto.

Ellis, Rod, Gary Barkhuizen 2005. Analysing Learner Language. Oxford: Oxford University Press.

Grönholm, Maija 2009. Inlärning av finska lokalkasus och deras semantisk-syntaktiska funktioner. - Maija Grönholm. Tidig inlärning av finska. Artiklar om språkbad - Artikkeleita kielikylvystä. Publikation från Pedagogiska fakulteten vid Åbo Akademi Nr 19. Vasa: Pedagogiska fakulteten, 196-207.

Ingo, Rune 2000. Suomen kieli vieraan silmin. Vaasan yliopiston käännösteorian ja ammattikielten tutkijaryhmän julkaisut 26. Vaasa: Vaasan yliopisto.

ISK 2004 = Hakulinen, Auli, Maria Vilkuna, Riitta Korhonen, Vesa Koivisto, Tarja Riitta Heinonen, Irja Alho 2004. Iso suomen kielioppi. SKS:n toimituksia 950. Helsinki: Suomalaisen Kirjallisuuden Seura.

Jantunen, Jarmo Harri 2011. Kansainvälinen oppijansuomen korpus (ICLFI): typologia, taustamuuttujat ja annotointi. - Lähivõrdlusi. Lähivertailuja 21, 86-105. http://dx.doi.org/10.5128/LV21.04

Jönsson-Korhola, Hannele, Leila White 1997. Tarkista tästä. Suomen sanojen rektioita suomea vieraana kielenä opiskeleville. Helsinki: Oy Finn Lectura AB.

Kaivapalu, Annekatrin 2005. Lähdekieli kielenoppimisen apuna. Jyväskylä Studies in Humanities 44. Jyväskylän yliopisto: Jyväskylä University Printing House.

Karlsson, Fred 2009. Finsk grammatik. Nionde utökade och reviderade upplagan. SKS:n toimituksia 339. Helsinki: Hakapaino Oy. 
Koivisto, Helinä 1994. Ulkomaalaissuomen syntaksia. Tampereen yliopiston suomen kielen ja yleisen kielitieteen laitoksen julkaisuja 17. Tampere: Tampereen yliopisto.

Koskela, Anne, Tiina Suni 2000. Oppimisjärjestys suomen kielen oppikirjoissa. Sanna Martin, Helena Sulkala (Toim.). Tutkielmia oppijankielestä. Suomen ja saamen kielen ja logopedian laitoksen julkaisuja N:o 17. Oulu: Oulun yliopisto, 129-158.

Lauranto, Yrjö 1997. Ensi askeleita paikallissijojen käyttöön. Espanjankielisten suomenoppijoiden sisä- ja paikallissijat konseptuaalisen semantiikan näkökulmasta. Kakkoskieli 2. Helsinki: Helsingin yliopiston suomen kielen laitos.

Lepäsmaa, Anna-Liisa, Leena Silfverberg 2009 (1998). Suomen kielen alkeisoppikirja. Helsinki: Oy Finn Lectura Ab.

Lähdemäki, Eeva 1995. Mikä meni pieleen? Ruotsinkielisten virheet suomen ainekirjoituksessa. Fennistica 11. Åbo: Åbo Akademi.

Manninen, Terhi, Sanna Martin 2000. Vieraskielisten ongelmia ylioppilasaineessa. - Sanna Martin, Helena Sulkala (Toim.). Tutkielmia oppijankielestä. Suomen ja saamen kielen ja logopedian laitoksen julkaisuja 17. Oulu: Oulun yliopisto, 73-89.

Martin, Maisa, Sanna Mustonen, Nina Reiman, Marja Seilonen 2010. On becoming an independent user. - Inge Bartning, Maisa Martin, Ineke Vedder (Eds.). Communicative Profiency and Linguistic Development: Intersections between SLA and Language Testing Research. Eurosla Monographs 1. European Second Language Association, 57-79.

Määttä, Tuija 2010. “Menen seuraavaan kursiin.” Korpuspohjainen tutkimus ruotsinkielisten suomenoppijoiden illatiivin ja allatiivin käytöstä kirjallisessa tuotannossa. - Pille Eslon, Katre Õim (Toim.). Korpusuuring ja meetodid. Tallinna Ülikooli Eesti Keele ja Kultuuri Instituudi toimetised 12. Tallinn, $101-126$.

Määttä, Tuija 2011. Ruotsinkielisten alkeistason suomenoppijoiden paikallissijojen käytöstä. - Lähivõrdlusi. Lähivertailuja 21, 154-184. http://dx.doi. org/10.5128/LV21.07

Määttä, Tuija 2012. Oppikirjan sanaston vaikutuksesta ruotsinkielisten alkeistason suomenoppijoiden kirjallisiin tuotoksiin. - Lähivõrdlusi. Lähivertailuja 22, 188-218. http://dx.doi.org/10.5128/LV22.07

Nissilä, Leena 2011. Viron kielen vaikutus suomen kielen verbien ja niiden rektioiden oppimiseen. Acta Universitatis Ouluensis B Humaniora 99. Oulu: Oulun yliopisto. 
Ranua, Minna-Mari, Margit Ruotsalainen 2007. Syntaktisten virheiden vertailua suomi toisena ja suomi vieraana kielenä -oppijoiden teksteissä. - Helena Sulkala, Maija-Liisa Halme, Hannakaisa Holmi (Toim.). Tutkielmia oppijankielestä III. Studia humaniora Ouluensia 5. Oulu: Oulun yliopisto.

Sajavaara, Kari 1999. Kontrastiivinen kielentutkimus ja virheanalyysi. - Kari Sajavaara, Arja Piirainen-Marsh (Toim.). Kielenoppimisen kysymyksiä. Soveltavan kielentutkimuksen teoriaa ja käytäntöä 7. Jyväskylä: Jyväskylän yliopisto, 103-128.

Siivelt, Keaty 2012. Lähdekielen vaikutus ja kielitaitotaso: vironkielisten oppijoiden sisäpaikallissijojen käyttö oppijansuomen korpuksessa. Julkaisematon MA-tutkielma. Tallinnan yliopiston viron kielen ja kulttuurin instituutti.

Varis, Klára 2010. Ajanilmaukset Cefling-hankkeen koululaisaineistossa. Julkaisematon pro gradu -tutkielma. Suomen kielen oppiaine. Jyväskylän yliopisto.

\section{Tuija Määttä}

Umeå universitet, Institutionen för språkstudier

S-901 87 Umeå, Sweden

tuija.maatta@finska.umu.se 


\title{
The functions of the local cases in texts written by Swedish-speaking beginners-level learners of Finnish
}

\author{
TUIJA MÄ̈̈TTÄ \\ Umeå University
}

This article investigates how frequently and in what functions Swedish-speaking beginners-level learners of Finnish use the six local cases. The specific focus of the article is on the comparison of correct and incorrect use of the local cases in their different functions. The investigation is corpus-based, and the material used in the study is the Swedish sub-corpus of the electronic corpus entitled The International Corpus of Learner Finnish. The texts were compiled during the period 2006-2009 at Umeå University. The research material, which was analysed using WordSmith Tools software contains a total of 43496 word tokens, of which 4408 are inflected in the local cases. The analysis to find out the different functions in which the local cases occur was carried out manually, because at the time of the analysis the corpus was not yet linguistically annotated.

The corpus is divided into four groups: place, time, verb government and others. The results show that learners use the local cases mostly to express concrete places. This is natural because on the beginners' level the most elementary functions of local cases are presented and learned. However, the material contains many occurrences of verbs that govern a local case, and there are also different types of expressions of time. The group designated "Others" includes occurrences of local cases in various functions, for instance, the adessive case expressing possessor, instrument, or vehicle.

In most expressions, the learners use the local cases correctly. Only in $7 \%$ of the expressions did the learners choose an incorrect local case; these errors are to be found mostly in expressions of concrete places and imply an overuse of the allative case. Expressions of time or verb-governed local cases seem to be easier for the learners. However, in expressions of time the adessive case is sometimes used incorrectly instead of the essive case which is not systematically presented in the beginners-level course. Incorrect adessive use instead of verb-governed allative also occurs frequently. 
The conclusion of this investigation is that Swedish-speaking beginnerslevel learners of Finnish have already mastered the basic functions and uses of the Finnish local cases, despite the fact that the expressions of local and directional relations in Swedish and Finnish are structured very differently, reflecting a different perception of the world. The results of this study can be utilized in teaching and in producing teaching materials for courses in Finnish as a foreign language.

Keywords: learner Finnish; Swedish-speaking learner; beginners-level; local cases; functions of the local cases; corpus-based investigation 